DOI 10.31558/2519-2949.2019.4.8

УДК $321: 327$

ORCID ID: https://orcid.org/0000-0001-7449-905X

Ярошенко В. М., Миколаӥвський національний університет

ім. В.О.Сухомлинського

\title{
РОЛЬ ТЕРИТОРІАЛЬНИХ ГРОМАД У ПРОЦЕСІ СТАНОВЛЕННЯ ІНСТИТУТУ ДЕМОКРАТИЧНОЇ ГРОМАДЯНСЬКОСТІ В УКРАЇНІ
}

У даному дослідженні визначаються особливості функиіонування територіальних громад в сучасній Україні як агентів інститучіоналізаиії демократичної громадянськості. Статичним чинником успішної діяльнісної моделі розвитку громад представляється територія, а динамічним чинником - громадянськість, яка персоналізується в колективах, об'єднаних спільною взаємодією на взаємну корисність. Колективна громадянськість у образі територіальних громад визначається агентом інституціоналізачії демократичної громадянськості. Стверджується закономірність визнання демократичної колективної громадянськості політичним інститутом $i$ спільнотою одночасно, а синтез соиіокультурного та стратегічного чинників розвитку громади $\epsilon$ необхідною умовою ї̈ залучення до сучасної політики у якості політичного актора. Аналізуються прачі вітчизняних і закордонних авторів з досліджуваної теми, зокрема прачя Елінор Остром «Керування спільним. Еволюиія інституиій колективної дїі». Серед методів дослідження авторські дослідження теми самоврядування протягом останніх років (2002-2018рр) та узагальнення власного досвіду депутатської та викладащької діяльності. Наголошується важливість об єднання територіальних громад для їх спроможності бути успішними. Індикатором розвинутості колективної громадянськості як спільноти визначається територіальна та начіональна ідентичність. Зокрема, територіальна ідентичність відіграє провідну роль у реформуванні місиевого самоврядування, територіальної організації держави та самоорганізаиії суспільства. Зосереджується увага на важливості дотримання науково обгрунтованих законодавчих норм і прочедури об єднання територіальних громад. Пропонуються рекомендації щодо ефективності подальшого розвитку територіальних громад, серед яких визначаються пріоритетними: зміџнення колективної солідарності, фінансової стійкості та підвищення громадянської компетентності.

Ключові слова: місиеве самоврядування, інститут демократичної громадянськості, територіальна громада, колективна діяльність через спільну взаємодію.

Територіальній громаді належить одна з провідних ролей у процесі становлення інституту демократичної громадянськості в Україні, набутті досвіду місцевої демократії активістами громади, у сприянні інституціоналізації демократичної громадянськості суспільства. Для підтвердження заявленої гіпотези у даному дослідженні розглянуті праці науковців, авторські дослідження теми самоврядування протягом останніх років (2002-2018pp) та узагальнення власного досвіду депутатської діяльності. . Пошук шляхів зміцнення європейської демократії, відповідального використання публічної влади на фоні глобальних викликів: посилення міграційних потоків з недемократичних країн, гібридних війн, загострення і мілітаризація конфліктів актуалізують і визначають тему дослідження. Наукова новизна даної теми полягає в дослідженні досвіду самоврядування територіальних громад як агентів інституціоналізації демократичної громадянськості..

В. О. Сухомлинський під «громадянськістю» розумів «складне соціально-психологічне явище, в якому органічно поєднуються інтелектуальний, емоційний, вольовий та практичний аспекти життедіяльності людини як творця матеріальних і духовних цінностей суспільства» [9]. Авторка визначає «Інститут демократичної громадянськості» як конструктивну якісну частину - (цінніснодіяльнісне ядро) громадянського суспільства, яка організована на об'єднанні свідомих активних компетентних національно-патріотичних громадян з високим рівнем політичної культури у політико-відповідальній співпраці з державною владою» [11]. Тобто, ми аналізуємо 
громадянськість через ї̈ сочіальне призначення у складі спільноти, територіальної громади, виявляємо ії здатність на самоорганізацію у політичному контексті. Метою даного дослідження $€$ встановлення ролі територіальної громади у процесі інституціоналізації демократичної громадянськості в Україні.

Вирішення наукових завдань забезпечило використання наступних методів дослідження: метод аналізу; метод історизації у вивченні історичних традицій самоврядування українців; нормативний метод при роботі над законодавчою базою функціонування місцевого самоврядування; системний метод при аналізі функціонування територіальних громад в сучасній Україні;, тощо.

Дослідження інституту місцевого самоврядування мають значний перелік закордонних i вітчизняних праць. На формування теорій місцевого самоврядування мали значний вплив представники утопічного соціалізму й комунізму (Т. Мор, Т. Кампанелла, Ш. Фур'є, Р. Оуен, А. Сен-Сімон, Ж.-Ж. Руссо та ін). Також впливовими були праці відомого британського вченого Дж. С. Мілля, який вважав, що головною сутністю інституту місцевого самоврядування $є$ залучення населення в управління, коли індивіди беруть участь в управлінні, то вони розуміють його результати Ш. Фур'є пов'язував соціальний прогрес з часом, коли основу суспільства складатимуть асоціації - «фаланги». Свої погляди він виклав у роботі «Новий господарський соцітарний світ» (1829 р.). Перший принцип існування фаланги - особиста свобода кожного. Фаланга матиме свої загальнообов'язкові норми, але вони видаються за згодою всього колективу та виконуються всіма свідомо, добровільно. Фаланги у Ш. Фур'є - автономні й незалежні одне від одного соціальні утворення. Вони не пов'язані між собою в єдину цілісну систему, хоча й координують свою діяльність. Центральна влада та їі апарат не мають права втручатися у внутрішнє життя фаланг, опікувати їх, керувати ними тощо. Будуючи теоретичну модель «нового морального світу», відомий англійський соціаліст-утопіст Р. Оуен вважав, що первинною одиницею, «молекулою» майбутнього ладу стане самодостатня комуна, «селище громад». Такі «селища громад» групуватимуться, за Р. Оуеном, у федерації національного масштабу (держави), а потім об'єднаються у масштабі міжнародному. Він розробив конституцію таких громад, за якою комуни повинні будуватися та функціонувати на основі колективної праці, громадської (і тільки громадської) власності, рівності прав і обов'язків усіх своїх членів тощо [10]. За результатами дослідження науковця Ю. Панейко у праці «Теоретичні основи самоврядування». ще з XVIII ст. у Франції проблемами місцевого самоврядування займалися фізіократи, більше відомі своїми дослідженнями в галузі економічної теорії. Приватну свободу людини фізіократи вважали необхідною передумовою для розвитку самоврядування. Один з найбільш відомих попередників фізіократів - маркіз Рене-Луі д’Аргенсон (1694 - 1757), сучасник більш відомого Монтеск'є, виступав, на відміну від останнього, за скасування будь-яких станових привілеїв. Спостерігаючи життя сучасного йому міста, д’Аргенсон дійшов висновку про необхідність міського самоврядування. В основі теорії, розробленої ним у «Трактаті про управління і демократію в монархічному суспільстві», лежить теза «Щоб управляти краще, треба управляти менше». Уся система міського самоврядування будувалася, за д’Аргенсоном, на виборній основі під наглядом інтенданта, якого призначав король. За словами Ю. Панейка, д’Аргенсон, «спираючись на голландські та фламандські зразки, вимагав визнати громади як так звані «демократії» або публічно-правні корпорації, привернути їм давню свободу - передусім право вільного вибору громадських органів - і право збирати податки» [8].

Загальна проблема, над якою працювала нобелевський лауреат Елінор Остром, - це проблема колективної взаємодії. Осмислюючи іï, американська дослідниця розробила теорію інституційних механізмів, пов'язаних з ефективним управлінням і керуванням спільними ресурсами. [7].

В украӥнській політико-правовій думці ми також знаходимо прихильників державницької моделі місцевого самоврядування. Зокрема, М. І. Туган-Барановський писав, що система муніципальних органів має йти поряд із системою державних органів, причому муніципалітети «повинні створювати певну ієрархію, починаючи від великих організацій, що охоплюють великі райони і великі групи населення аж до найменших з населенням у кілька тисяч чи навіть сот родин». В основу ж компетенції головних одиниць місцевого самоврядування має бути покладено сформульований ученим політико-економічний принцип: «Кожна муніципальна організація повинна мати своє власне господарство, до того ж у розподілі господарських завдань між державними й іншими муніципалітетами повинно бути покладене правило, щоб усе, що має бути виконано муніципалітетами, покладалося на останні. Центральна державна влада мусить брати на себе лише те, що явно не під силу муніципалітету». За державою залишається загальна наглядова, спрямовуюча і регулююча влада. Отже, широке місцеве самоврядування, на думку 
M. I. Тугана-Барановського, має стати «першим корективом» до «централізуючого начала державності» [6].

Розуміння місцевого самоврядування знайшло своє втілення в Конституції України, а також у чинному Законі України "Про місцеве самоврядування в Україні" (далі - законі), в якому, зокрема, зазначається: "Місцеве самоврядування в Україні- це гарантоване державою право та реальна здатність територіальної громади - жителів села чи добровільного об'єднання у сільську громаду жителів кількох сіл, селища, міста - самостійно або під відповідальність органів та посадових осіб місцевого самоврядування вирішувати питання місцевого значення в межах Конституції і законів України" [2], [3].

Визначення в Конституції та законах України місцевого самоврядування, хоч би яке досконале воно було, далеко не вичерпує до кінця змісту цього суспільно-політичного явища, а тому не зводиться лише до гарантованого державою права територіальних громад і тих органів, які вони обирають (органів місцевого самоврядування), самостійно вирішувати якусь частину публічних справ. При вивченні місцевого самоврядування важливо пам'ятати, що це - один з основоположних принципів організації публічної влади на місцях у державі, яка прагне стати правовою, а також форма самоорганізації місцевого населення.

Місцеве самоврядування як принцип організації публічної влади на місцях безпосередньо, відповідно до ст. 2 Європейської хартії, знайшло своє втілення в Конституції України (ст. 7), а отже, стало однією з конституційних основ нашої держави.

Концептуальні положення громадянськості, розроблені авторкою, визначають індивідуальну громадянськість базовим компонентом колективної громадянськості. 3 часом колективна спільнота шляхом агрегування та артикуляції інтересів перетворюється в громаду, що стає залученою до державної політики. У контексті колективної громадянськості громада стає найвпливовішим політичним актором, вона часто ініціює, впроваджує, оцінює та коректує національну політику. Тобто, громадянськість у соціально-політичному аспекті ціккавить авторку як спільнота, де здійснюється колективна діяльність через спільну взаємодію.

Чинники, які вказують на посилення ролі у суспільстві територіальної громади. По-перше, реформа місцевого самоврядування в сучасній Україні сприяла колективній діяльності через спільну взаємодію, щцо, в свою чергу, стало регулятором взаємовідносин, системоутворюючим чинником становлення інституту демократичної громадянськості. Громадяни збираються разом для обговорення стратегії і пошуку варіантів успішного використання довгоочікуваного шансу стати господарями своєї території, визначають спільні інтереси і планують раціональне використання фінансових ресурсів для ï перспективного розвитку. Територія - це, один із статичних чинників, який пробуджуючи громадянськість, мотивує громадян до прояви діяльнісної моделі поведінки. Тобто, визначення пріоритетної ролі громадянськості-у прояві її як любові до рідної землі, цінності території підтвердилося у трагічному 2014 році. Тоді громадяни, ризикуючи своїм життям, стали на захист національної території від російської агресії. По-друге, політичний контекст ця колективна діяльність набуває у межах дворівневого політичного процесу:1).використання іiі стратегічного потенціалу регіональною владою для встановлення легітимного порядку 2).активне залучення національної ідентичності регіональною громадою для здійснення впливу на процес прийняття політичних рішень регіональною або загальнонаціональною владою. Після досвіду двох революцій- Помаранчевої революції та революції Гідності, відносини влади і громади почали набувати діалогічної партнерської моделі. По-третє, динамічними чинниками становлення інституту демократичної громадянськості можна вважати, за різними показниками, підвищення громадянської політичної культури та громадянської політичної відповідальності.. Загрозливі випробування втратитою демократичних цінностей незалежної державності, свободи, гідності, прав людини, безпеки кінця 2013-початку 2014 року стали каталізатором пробудження громадянськості(патріотизму) у значної кількості громадян (показники до 76\%). Відстоювання цих цінностей дорівнювало трагічній соціальній ціні. Пробудження у громадян цінності громадянськості у процесі боротьби відображає якісний зміст поняття «громадянин», але свідчить про незрілість і некомпетентність цього функціонального інституту. Зрілість і компетентність громадянськості має визначатися постійною традиційною співпрацею з владою у публічному управлінні, публічних консультаціях, створенні демократичного середовища, що $є$ у демократичних країнах умовами збереження демократії. На наш погляд, саме інститут демократичної громадянськості $\epsilon$ такою моделлю. Набуття демократичної пильності, громадянської компетентності через залучення громадян до публічного управління та громадянську освіту в сучасній Україні $€$ беззаперечно 
своєчасним. Оскільки високий відсоток прояву громадянськості (патріотизму) серед українських громадян виступає статичним чинником організації територіальної громади і одночасно агентом оформлення інституту демократичної громадянськості. Тобто, синергія ціннісно -дієвого компоненту громадянськості виокремлює його як ядро омадянського суспільства. За останні роки в Україні проявилися за діяльнісним принципом (конкретними діями) колективи однодумців в суспільстві, які проявляють себе перспективними структурними компонентами інституту демократичної громадянськості. Це багаточисельні добровільні громадські організації та об'єднання, частину з яких - територіальні громади ми визначили суб'єктами вивчення у нашому дослідженні уякості агентів становлення інституту демократичної громадянськості. За результатами дослідження внутрішніх і зовнішніх параметрів громадянськості, за останні роки громадянськість проявилася як конвертація іiі у героїчному захисті національної території, незалежності ( волонтери, добровольц)і консолідації інтересів навколо спільної власності (активісти територіальної громади, фермери), реалізації креативного мислення через інноваційні моделі реформування основних сфер суспільного життя( науковці, молоді вчені, студентське самоврядування). Слід визнати, що це тільки менша частина громадянського суспільства, оскільки ще значна його частина вважається предствниками громадянського суспільства, але не проявила себе активними учасниками трансформаційних та випробувальних змін. Більше того, частина громадян відсторонилася від обов язків громадян( несплата податків, тіньові схеми економічних відносин). На жаль, залишається багато проявів девіантної поведінки та громадянської «мімікрії», коли громадяни вдаються до посягання на державну власність або власність інших громадян, часто видаючи себе за поважних громадян.. Саме тому метою даного дослідження ми визначили .3-поміж загал громадянського суспільства його ціннісно-діяльнісне ядро- громадянськість, спроможного скерувати вектор політичного розвитку у бік європейської демократії. Консолідація цієї свідомої активної частини громадянського суспільства набирає поступу і,на нашу думку, в сучасній Украӥні настав етап переходу від персоналізації вокремих громадянах иінності громадянськості, представниках національної еліти, до персоналізаиї иінності громадянськості в колективах, об'єднаних спільною взаємодією на взаємну корисність. Тобто, агентами суспільних змін виступають не тільки і не скільки окремі громадяни, а їх колективна взаємодія як прояв креативного класу. Безумовно, супротив і перешкоди цьому процесу є багаточисельні, але загальна тенденція виглядає переконливо.

Оскільки культурні(соціокультурні) характеристики колективної громадянськості пов'язані з іiі об'єктивними особливостями, а стратегічні - 3 політикою національної ідентичності, то можна припустити, що:

1. Стратегічний i соціокультурний потенціал ідентичності громадянськості робить іiі політичним інститутом і спільнотою одночасно.

2. Синтез соціокультурного та стратегічного чинників розвитку громади $є$ необхідною умовою iï залучення до сучасної політики у якості політичного актора.

3. За умов порушення такого синтезу громади будуть використовуватись у політичних іграх, втрачаючи можливість артикуляції та агрегування власних інтересів при повному підкоренні регіональної політичної еліти державним органам влади.

Отже, головним індикатором розвинутості колективної громадянськості як спільноти $\epsilon$ територіальна та начіональна ідентичність. Зокрема, територіальна ідентичність відіграє провідну роль у реформуванні місцевого самоврядування, територіальної організації держави та самоорганізації суспільства.

Особливості функціонування територіальноі громади в сучасній Україні. Поступальний процес демократизації змусив Уряд з 2014 року розпочати реформу в межах чинної Конституції. 3 того часу сформований і діє основний пакет нового законодавства, впроваджуються першочергові законодавчі ініціативи такі як Закони про внесення змін до Бюджетного та Податкового кодексів України. Завдяки цим змінам відбулася фінансова децентралізація: місцеві бюджети за останні роки зросли на 123,4 млрд грн: 3 68,6 млрд в 2014 до 192 млрд грн в 2017 році. Частка місцевих бюджетів у зведеному бюджеті України постійно зростає і на кінець 2017 року склала 51,2 \% (у 2015 році$45,6 \%[1]$.

Прийняття пакету законів щодо розширення повноважень органів місцевого самоврядування та оптимізації надання адміністративних послуг дозволило делегувати органам місцевого самоврядування відповідного рівня повноваження з надання базових адміністративних послуг: реєстрацію місця проживання, видачу паспортних документів, державну реєстрація юридичних та 
фізичних осіб, підприємців, об’єднань громадян, реєстрацію актів цивільного стану, речових прав, вирішення земельних питань тощо.

Нова законодавча база значно посилила мотивацію до міжмуніципальної консолідації в країні, створила належні правові умови та механізми для формування спроможних територіальних громад сіл, селищ, міст, які об'єднують свої зусилля у вирішенні нагальних проблем. Також переконливо виправдовує себе нова модель фінансового забезпечення місцевих бюджетів, які отримали певну автономію і незалежність від центрального бюджету.

Уряд визначає підтримку реформи децентралізації в Україні одним з пріоритетних завдань, що сприятиме розвитку місцевого самоуправління і економічного розвитку країни в цілому. Очікується, що більшість існуючих малочисельних місцевих рад можуть об'єднатися, що стане ключовим у питанні формування базового рівня місцевого самоврядування:, а отже стати спроможними перебрати на себе більшість повноважень, належним чином використовувати ресурси і нести відповідальність за свої дії чи бездіяльність перед людьми та державою. Це створить стійке підгрунтя для наступних кроків реформи місцевого самоврядування, а також сприятиме прискоренню реформ у сфері охорони здоров'я, освіти, соціальних послуг, енергоефективності та інших секторах.

Слід врахувати, що процес реформування відбувається в умовах значного гальмування як з причини психологічного супротиву запровадженню інновацій, так і з причини попереднього довготривалого виховання патерналізму у свідомості громадян за часів радянської влади. Тоталітарний політичий режим вдавався до тотального узалежнення та звуження ініціативи своїх громадян, що і проявляється у моделях поведінки супротиву сьогоднішнього реформування місцевих громад. 3 власного досвіду депутатської діяльності (2002-2006pp), прикладів численних спротивів вирішенню питань на користь виборців за участі самих виборців можна навести досить значну кількість. Так, наприклад, у депутатській спланованій акції з вимоги поновлення опалювання у помешканнях 300 виборців складно було умовити хоча би невелику їх представницьку групу для підсилення тиску на владу для позитивного прийняття рішення. Виборці елементарно боялися влади, 3 недовірою ставилися навіть до очевидно корисних для них пропозицій. За весь термін чотирьох років повноважень найлегше було вирішувати численні проблеми виборців округу і найважче вдавалося навчити самих виборців вирішувати свої проблеми. При тому, найефективнішими методами вирішення проблем округу було залучення самих виборців до попереднього обговорення, прийняття спільного варіанту вирішення тих чи інших проблем. Тому підтвердженням $\epsilon$ розуміння причини більш повільного процесу реформування місцевого самоврядування ніж планувалось. Має бути кропітка просвітницька та переконлива робота, щоб змінити у свідомості людей недовіру та супротив реформуванню. Оскільки свідомість - досить інертна сфера.

Попередні до реформування роки на всіх рівнях суспільних обговорень важливою темою була тема децентралізації. Складно було сподіватися, що влада реально погодиться поділитися своїми владними повноваженнями. Декларована демократія у нормах Конституції України до 2014 року, початку реформування місцевого самоврядування, видавалася схожою до «скляної стелі» - норми закону $\epsilon$, але реалізувати їх неможливо. Отже, зараз децентралізація стала можливою- це передача повноважень та фінансів від державної влади якнайближче до людей- органам місцевого самоврядування. Кожен мешканець села чи міста має право на сучасну медицину й освіту, доступні та якісні адміністративні, комунальні, соціальні послуги, гарні дороги, чисті й освітлені вулиці. Але люди можуть впливати на якість цих послуг лише тоді, коли відповідальні за їх надання знаходяться близько. Найближчою до людей владою $\epsilon$ органи місцевого самоврядування: сільські, селищні міські ради та їхні виконкоми. Отже саме вони повинні мати широкі повноваження і достатньо коштів, щоб бути спроможними вирішувати усі місцеві питання і нести за це відповідальність. Щоб переконатися у доцільності та корисності реформування територіальної громади, наведемо конкретні статистичні дані. Так, на сьогодні в Україні 4277 місцевих рад об'єдналися у 924 спроможні громади. 3 них 33 - це міста обласного значення, які приєднали до себе більше 70 навколишніх місцевих рад У відомстві Мінрегіону зазначили, що це ті громади, які не побоялися взяти відповідальність у свої руки за розвиток територій і налагодження нормального життя для своїх мешканців, спираючись на децентралізацію. «За цими цифрами стоїть якісний розвиток місцевого самоврядування, а за ним - ефективні рішення на користь громад, доступні послуги для людей і вирішення всіх тих проблем у селах і містах, які не вирішувалися роками, а тільки поглиблювалися. На території об'єднаних громад проживає 
10 мільйонів населення. Наше спільне з органами місцевого самоврядування i місцевими адміністраціями завдання - втілити реформу на всій території країни, щоб всі люди отримували необхідні послуги належної якості, щоб створювалися робочі місця там, де вони живуть, щоб їх населені пункти ставали для них комфортними і безпечними», - 3 повідомлення Мінрегіону, яке посилається на дані Моніторингу процесу децентралізації та реформування місцевого самоврядування станом на 10 липня 2019 року [5].

Умовами подальшого успішного становлення інституту місцевого самоврядування с спроможність територіальних громад, Зокрема:

- Спроможна ОТГ (об’єднана територіальна громада) має самостійно або через відповідні органи місцевого самоврядування забезпечити належний рівень надання послуг, зокрема у сфері освіти, культури, охорони здоров'я, соціального захисту, житлово-комунального господарства з урахуванням кадрових ресурсів, фінансового забезпечення та розвитку інфраструктури іншої адміністративно-територіальної одиниці.

- Важливим є створення Перспективного плану згідно Методики формування спроможних територіальних громад 2015 [4]. Методика вчить спочатку визначитися 3 потенційним адміністративним центром майбутньої громади, як центру здатного надати соціальні, адміністративні та економічні послуги, а потім формувати громаду, враховуючи зони доступності на відстані 20-25 км від вибраного центру.

- чисельність населення (рекомендовано не менше 5000 мешканців) і площа (не менше 200 кв. км.) - це перша позиція, яка на 60-70\% визначає спроможність громади. Ця позиція пов’язана 3 кадровим наповненням громади, можливістю надати якісні освітні послуги, відсутності монополій підприємницьких структур і фермерів, наповнення бюджету (земельний податокосновний ресурс місцевого самоврядування) тощо;

- мають бути приєднані до історично сформованих центрів ті громади, які мають центри, що знаходяться на відстані менше 5 км від міста обласного значення чи центру району. до історично сформованих центрів;

- важливою ознакою спроможності громади є ї фінансова стійкістю і рівень дотаційності майбутньої громади. Від цього залежить бюджет і майбутнє підгрунтя для розвитку;

- слід врахувати демографічну ситуацію в громаді і дані статево-вікової піраміди.

- вкрай важливою умовою успішної громади є ініціативна і відповідальна команда.

Доцільність прописаних умов спроможності територіальних громад як і позитивні результати самої децентралізації підтверджуються результатами проведеного опитування студентів МНУ ім В.О.Сухомлинського, які навчаються на денній i заочній формі навчання i $є$ представниками територіальних громад південних областей України: Одеської, Миколаївської, Запорізької та Херсонської областей. Серед опитаних 47 респондентів - 45 відповіли схвально на запитання «Чи помітні позитивні зміни децентралізації?», 1 - «Не помітні тому, що і до початку реформи було не гірше» ( Нова Одеса, Миколаївської області), 1 - «Зовсім нічого не змінилося через корупцію»(Первомайськ, Миколаївської області. У 45 респондентів на запитання «Що саме змінилося на краще?» відповіді схожі - «Покращилася інфраструктура - відремонтовано школу, дитячий садок, клуб, дороги, освітлені вулиці, поновлено транспортне сполучення». На запитання «3 чим саме повязані позитивні зміни?»- 32 респонденти визначили переобрання керівників громади, тобто прийшли нові люди, більш компетентні і відповідальні і зміни на краще стали помітними. На запитання: «Чи плануєте ви після закінчення навчання працювати і жити дома, на територіїі своєї територіальної громади?» відповіді поділилися наступним чином: «Поки вагаюся»-27, «Точно ні»- 13, і «Так»- всього лише - 7. Отже, студентська молодь, прагматично оцінює зміни, замислюється над планами на майбутнє, але ще не відчуває себе суб'єктами змін. Включення студентської молоді в процес трансформаційних перетворень заслуговує на окремі наукові дослідження.

Висновки. За результатом досліджуваної теми можна погодитися 3 тим, що територіальній громаді належить одна 3 провідних ролей упроцесі становлення інституту демократичної громадянськості в Україні, зокрема:

- інститут місцевого самоврядування в Україні проходить етап інституціоналізації і має всі шанси бути одним із провідних у становленні інституту демократичної громадянськості;

- переконливий досвід успішної реалізації перших років здійснення реформи місцевого самоврядування надає оптимістичні прогнози на його успішне продовження. 
Вироблено наступні пропозиції співпраці місцевого самоврядування з науковцями, експертами, представниками ЗМІ, щодо їх подальшого розвитку та підвищення ролі територіальних громад у сприянні становленню інституту демократичної громадянськості:

1. Започаткувати практику співпраці територіальної громади з науковими установами, закладами вищої освіти для проведення короткотермінових тематичних семінарів, тренінгів, конференцій для активістів територіальних громад .

2. Поширювати інформацію про успіхи, яких вдалося досягти у діяльності громад, створюючи позитивний імідж територіальної громади. Оскільки це ствоює позитивний вплив на менш впевнених у успішних результатах активістів громади.

3. Розробляти реальні проекти залучення коштів на баланс громади, сприяти організації нових робочих місць та удосконалення інфраструктури.

4. Залучати якомога бльше молоді до процесу реформування, сприяючи їх працевлаштуванню та забезпеченню житлом.

Дослідження функціонування територіальних громад в сучасній Україні надає можливість стверджувати, .що процес функціонування територіальних громад, залучаючи активних громадян до вирішення основних проблем, в першу чергу, місцевого значення, сприяє визначенню груп інтересів та формування нової генерації національної еліти. Тобто, ефективне функціонування місцевого самоврядування може мобілізувати потенційні ресурси в достатню критичну масу громадянської енергії для спрямування вектору політичного розвитку до стійкої євроінтеграції. Оскільки громадяни у практиці самоврядування набувають лідерських якостей, персоналізацією якої є громадянськість патріотів України.

\section{Бібліографічні посилання:}

1. Закони про внесення змін до Бюджетного та Податкового кодексів України. Децентралізація в Україні: досягнення, надії та побоювання URL:http://www.international-

alert.org/sites/default/files/Ukraine_Decentralisation_UK_2017

2. Закони України "Про місцеве самоврядування в Україні"1997, URL: https://zakon.rada.gov.ua/laws/ show/ 280/97-\%D0\%B2\%D1\%80

3. Конституція України, 1996, URL: 2002. 196c. https://zakon3.rada.gov.ua/laws/show/254\%D0\%BA/ $96-\% \mathrm{D} 0 \% \mathrm{~B} 2 \% \mathrm{D} 1 \% 80$

4. Методики формування спроможних територіальних громад, затвердженої постановою Кабінету Міністрів України від 8 квітня 2015 року № 214, URL: https://novodrayrada.mk.ua/detsentralizatsiya/ 654-metodika-formuvannya-spromozhnikh-teritorialnikh-gromad

5. Моніторинг процесу децентралізації та реформування місцевого самоврядування станом на 10 липня 2019 року, https://decentralization.gov.ua/mainmonitoring

6. Основи етнодержавознавства : підруч. для студ. гуманіт. спец. вищ. закл. осв. / за ред.

Ю. І. Римаренко, Київ, Либідь, 1997. 656 с.

7. Остром Елінор Керування спільним. Еволюція інституцій колективної дії. 2017,

URL: https://naturalworld.guru/kniga_keruvannya-spilnim-evolyuciya-instituciy-kolektivnoyi.htm

8. Панейко Ю. Теоретичні основи самоврядування. Львів: Літопис, 2002. 196 с.

9. Сухомлинский В. А. Рождение гражданина. Москва: Мол. гвардия, 1971. 336 с.

10. Филиппов Ю. В., Авдеева Т. Т. Основи развития местного хозяйства: учебник. Москва, 2000. С.17.

11. Ярошенко В.М. Вплив мережевої комунікації на становлення інституту демократичної громадянськості в Україні. Наукові праџі: Чорноморського наи. ун-ту ім. Петра Могили.Сер.Політологія / ред. кол.Іванов М.С. Миколаїв, 2019.Т. 297. Вип. 285. С.58-64.

\section{References:}

1. Zakony pro vnesennya zmin do Byudzhetnoho ta Podatkovoho kodeksiv Ukrayiny. Detsentralizatsiya v Ukrayini: dosyahnennya, nadiyi ta poboyuvannya URL:http://www.international-alert.org/sites/default/ files/Ukraine_Decentralisation_UK_2017

2. Zakony Ukrayiny "Pro mi- stseve samovryaduvannya v Ukrayini"1997, URL: https://zakon.rada.gov.ua/ laws/show/ 280/97-\%D0\%B2\%D1\%80

3. Konstytutsiya Ukrayiny, 1996, URL: 2002. 196s. https://zakon3.rada.gov.ua/laws/show/254\%D0\%BA/ $96-\% \mathrm{D} 0 \% \mathrm{~B} 2 \% \mathrm{D} 1 \% 80$

4. Metodyky formuvannya spromozhnykh terytorial'nykh hromad, zatverdzhenoyi postanovoyu Kabinetu Ministriv Ukrayiny vid 8 kvitnya 2015 roku № 214, URL: https://novodrayrada.mk.ua/detsentralizatsiya/654metodika-formuvannya-spromozhnikh-teritorialnikh-gromad

5. Monitorynh protsesu detsentralizatsiyi ta reformuvannya mistsevoho samovryaduvannya stanom na 10 lypnya 2019 roku, https://decentralization.gov.ua/mainmonitoring

6. Osnovy etnoderzhavoznavstva : pidruch. dlya stud. humanit. spets. vyshch. zakl. osv. / za red. YU. I. Rymarenko, Kyyiv, Lybid', 1997. 656 s. 
7. Ostrom Elinor Keruvannya spil'nym. Evolyutsiya instytutsiy kolektyvnoyi diyi. 2017, URL: https://naturalworld.guru/kniga_keruvannya-spilnim-evolyuciya-instituciy-kolektivnoyi.htm

8. Paneyko YU. Teoretychni osnovy samovryaduvannya. L'viv: Litopys, 2002. 196 s 9. Sukhomlynskyy V. A. Rozhdenye hrazhdanyna. Moskva: Mol. hvardyya, 1971. 336 s.

10. Fylyppov YU. V., Avdeeva T. T. Osnovy razvytyya mestnoho khozyaystva: uchebnyk. Moskva, 2000. S.17.

11. Yaroshenko V.M. Vplyv merezhevoyi komunikatsiyi na stanovlennya instytutu demokratychnoyi hromadyans'kosti v Ukrayini. Naukovi pratsi: Chornomors'koho nats. un-tu im. Petra Mohyly.Ser.Politolohiya / red. kol.Ivanov M.S. Mykolayiv, 2019.T. 297. Vyp. 285. S.58-64.

Yaroshenko V. M. The role of territorial communities in the process of establishing the institute of democratic citizenship in Ukraine

This study identifies features of functioning of territorial communities in modern Ukraine as agents of institutionalization of democratic citizenship. Territory is a static factor in a successful community development model, and citizenship is a dynamic factor, which is personalized in teams that work together to work together for mutual benefit. Collective citizenship in the image of territorial communities is determined by the agent of the institutionalization of democratic citizenship. The legitimacy of recognizing democratic collective citizenship as a political institute and community is affirmed, while the synthesis of socio-cultural and strategic factors of community development is a necessary condition for its involvement in contemporary politics as a political actor. The works of domestic and foreign authors on the studied topic are analyzed, in particular the work of Elinor Ostrom "Managing the Common. The evolution of collective action institutions. "Among the research methods are the author's research on the topic of self-government in recent years (2002-2018) and the generalization of his own experience of deputy activity. The importance of uniting territorial communities for their ability to be successful is emphasized. The indicator of the development of collective citizenship as a community is defined by territorial and national identity. In particular, territorial identity plays a leading role in reforming local self-government, territorial organization of the state, and self-organization of society. Emphasis is placed on the importance of adhering to scientifically grounded legislation and procedures for the unification of territorial communities. Recommendations are given on the effectiveness of further development of territorial communities, among which priorities are identified: strengthening of collective solidarity, financial stability and enhancement of civic competence.

Key words: local self-government, institute of democratic citizenship, territorial community, collective activity through joint interaction. 